\title{
Determining Factors in the Evaluation of the Modular Plan for Libraries
}

Dr. Ellsworth is director of libraries, State University of Iowa.

E VALUATion of the modular method of planning libraries has, since 1943 , focused too often on side issues and irrelevancies. Thus when one hears discussions among librarians of how to carry ventilation ducts through columns, or whether a modular library must use the "divisional" type of organization, one can be certain that misunderstandings exist.

Responsibility for this misunderstanding would seem to be about equally divided between those of us who did the first talking and the natural human tendency to relate things that happen at the same time even though they have no connection. Everyone remembers that the first automobiles had a whip holder.

The critical points around which evaluation of the modular idea should take place seem to fall into two categories: program planning and construction techniques. This article will attempt to state and discuss the relevant points in each category.

\section{First, Program planning}

Is the modular idea applicable to one theory of college or university library plan, or can it be used for all known types of organization?

Unfortunately, because of my connection with the development of the University of Colorado subject divisional plan of organization, it was assumed that the same plan would be imported to Iowa. And when we announced our intention to adopt the modular idea, it was inevitable, it seems, that the idea would get around that modular and divisional were inseparable.

Our choice of a non-divisional plan at Iowa was based not on dissatisfaction with the divisional plan, but on our desire to experiment with other new ideas. And that is what we have done.

Proof of the adaptability of the modular idea lies no longer on claims but in the operation of existing buildings. At Princeton in the below-ground levels one can find a variety of patterns: administrative offices, reserve rooms, seminars, staff rooms, open and closed stacks, oases and research quarters. In the Iowa building there are at least three different types of organization, and the only thing they have in common is open stacks. The organization of service in the North Dakota State College Library, the North Carolina College for Women, and Bradley are entirely different from one another, and from Princeton, Iowa, or Washington State.

Ironically, one can find all kinds of organization in these libraries except the subject divisional arrangement that was used at Colorado.

It is true that the architects of these buildings have used a low spread-out style, but so have the architects of most of the new non-modular buildings. Modules can be stacked in whatever manner the architect wishes. It is also true in these buildings that there has been a tendency to use the open shelf plan, and to achieve an informal uninstitutional mood. The same can be said of the non-modular buildings. 
Are modular buildings more expensive to staff than other types? The staff costs of a particular building may be a factor of the plan of organization, or of the physical layout and features of the building, and it is not always easy to assign responsibility. Thus, in making comparisons between types of buildings in terms of staffing costs, care must be taken lest the results be invalid.

Because of the current stress on the public service aspect of university librarianship most of the newer buildings, - modular or otherwise, have larger staffs than did their predecessors. But when staff size of various libraries is compared with other factors such as size of the book collection, enrollment, dollars spent for books, it is clear that the element of modularity has nothing to do with the size of the staff.

Perhaps it could be said that a librarian who would choose a modular building would be the kind of librarian that would emphasize the teaching and research role of the library rather than the storage concept. And it can be assumed that storage libraries require smaller staffs than do "teaching" libraries. Except for this possible indirect relationship, staff size is a resultant of other factors.

\section{Second, Construction techniques.}

Do modular libraries violate traditional laws of aesthetics? This question should be considered thoughtfully by anyone who bears the responsibility of planning a library, because as Dean Hudnut pointed out in his address to the New England Library Association in $1948,{ }^{1}$ libraries belong in the humanistic tradition, Dean Hudnut pleaded with librarians not to let their zeal for functional buildings lead them into the trap of planning buildings that would not be supremely beautiful. Ralph Walker in a fine rage lashed out against the

\footnotetext{
1 Hudnut, J. "Architects and Librarian." Library
Quarterly, 18:93-9 April i 948 .
}

lack of traditional beauty in modular libraries. (Books in Libraries: Printed for the Friends of the M.I.T. Libraries. Portland, Me. July '5i.) The latter, by the way, spoke before he had seen one.

Both of these men were right, to some extent. The interiors of existing modular libraries are not beautiful in the same way that the interior of older buildings-such as the Boston Public, or Harper Library at Chicago, or the Deering Library at Northwestern-are. There are no rooms that are gems of architectural genius. There is a lack of form, in the traditional sense, in these buildings, and this is of course heresy to many architects, just as the writing of Hemingway, Lewis or Faulkner, or the drawings of the Abstract School are to the more traditionally minded in those fields of art.

But this does not mean that Ralph Walker is necessarily right in the long run. The librarians who have to manage one of the older buildings are likely to agree that the aesthetic qualities and the utilitarian qualities are two separate things entirely. Perhaps the aesthetic justification of the modular building lies in the beauty of their fine functioning of services. To a librarian, this is desirable; to a traditionally minded architect, blasphemy. Frank Lloyd Wright's statement in the October issue of the ALA Bulletin, p. 293, indicates that he might approve. The lack of style in the exterior of most of the modular buildings seems to bear out Mr. Wright's statement that no one knows just what a library should look like, if it is supposed to look like a library and not a church. Mere wrapped-up space is not yet accepted as a thrilling concept to architects, or to laymen.

For over a century architects have had their way. Perhaps librarians can be forgiven for daring to assume a belligerent attitude. 
Are modular libraries more or less expensive than other types? This question is so complicated that the writer is of the opinion that it cannot be answered objectively at the present time. The dilemma arises from the fact that measuring costs in terms of cubic feet is no longer meaningful. Cost per square foot is the only useful measure, and in calculating the square foot costs of a traditional building, there are problems. For instance, how do you count the stacks, stairwells, and other service units? No one thus far has had time to work out a simple rule for making the comparisons accurately, and until this is done, cost comparisons are not possible.

Nor are other kinds of measures such as cost per reader, or per book stored, valid. In a modular library, with its interchangeable space, the most one can say of a given building is that "with space for $\mathrm{x}$ readers, $x$ number of books can be housed." Figures on costs per reader or per book housed are meaningless in this situation.

It is true that assertions have been made about the short and long term economies of modular libraries, and it is the writer's opinion that these guesses were not too far wrong, but as things now stand the proof is not yet spelled out.

What about the wisdom of using the columns for ventilation ducts? Angus S. Macdonald developed an excellent and economical method of constructing columns so that they could also be used as air ducts, and it was therefore natural that many of us associated the modular idea with his method of construction. It is, in the writer's judgment, unfortunate that more libraries did not use Macdonald's invention, but actually there need be no relation between the two. Air can be circulated to all parts of a modular building through the ceilings without involving the columns at all. Indeed, in view of the ignorance one finds in the typical ventilation "engineer," there are good reasuns for using traditional methods only. A good engineer can, of course, achieve gcod results at a low cost with Macdonald's method, and with others.

What about low ceiling heights? All the predictions by architects (See Minutes of the Cooperative Committee on Library Building Planning) about the depressing effects of low ceilings in reading rooms have not been borne out by the facts. In the Iowa building (whose ceiling heights$8^{\prime} \frac{1}{2}=$ are the lowest of all the modular building), for instance, no one pays any attention to the ceilings unless attention is called to them.

But low ceilings have no virtue in themselves (except as they make it easy to provide good lighting). What then is the point of using them? One of the claimed virtues of modular buildings is their flexibility. Reading room space converted to stack space should not waste space above the book ranges. Thus, the nearer the ceilings can be brought down to $8^{\prime}$ the better. The Iowa building shows that this can be done, but also that it need not be done.

The calculation behind this statement proves the point. Since the stack ceiling heights are $8^{\prime} \frac{1}{2}{ }^{\prime \prime}$ and the stacks are 8 shelves (or almost $8^{\prime}$ ) we waste less than four inches above them. Call this a one foot waste. In the reading areas we save the difference between $8^{\prime}$ and $15^{\prime}$, or $7^{\prime}$. Then: 40,000 sq. $\mathrm{ft}$. in stack floor $X$ I cu. $\mathrm{ft}$. waste $=40,000 \mathrm{cu}$. ft. wasted. 80,000 sq. $\mathrm{ft}$. in reading room floors $\times 7 \mathrm{cu}$. $\mathrm{ft}$. saved $=560,000 \mathrm{cu}$. ft. saved.

This calculation suggests that one could afford to be more generous with the ceiling height if this is desired.

How big should the modules be? No final answer can be given to this question. In fact, the writer ventures the assertion that as long as the columns are spaced at distances $20 \mathrm{ft}$. or more, the question is not 
very important in terms of floor space utilization. It may be in terms of construction costs. In theory, if you approach the problem by measuring the number of feet required for tables, isle widths, distances between table edges and stacks, etc., you arrive at figures somewhat as follows: (And, of course, one should achieve the utmost economy in the use of floor space.)

Assuming the following basic distances:

Stack range length-units of 3 feet plus 4 inches for range ends

Table widths -43 inches

Table lengths-6, 9, 12 feet

Distance between tables- 5 feet

Distance between tables and stacks-6 feet

Stack Centers- $+\frac{1}{2}$ feet

The smallest practical reading room dimension for a module would appear to be $24^{\prime} 2^{\prime \prime}$ from edge of column, to edge of column (size of column not important in this connection unless larger than $\left.18^{\prime \prime}\right)$. This figure is developed as follows:

$6^{\prime}$ From edge of stack to ist table.

$43^{\prime \prime}$ Table width

$5^{\prime}$ Between tables

$43^{\prime \prime}$ Table width

$6^{\prime}$ From edge of table to edge of stack

$24^{\prime} 2^{\prime \prime}-18^{\prime \prime}$ for column or $25^{\prime} 8^{\prime \prime}$ between column centers

But it is necessary to assume that the same space will some day be used for book storage. If stacks are spaced on $4^{\frac{1}{2}}{ }^{\prime}$ centers, five ranges take $22 \frac{1}{2}^{\prime \prime}$ and six take $27^{\prime}$.

'Thus, it would appear that in the interest of economy of floor space utilization it would be best to use a dimension of $27^{\prime}$ between column centers along one of the sides of a module, and when the space is used for reading room purposes, spread out the tables slightly more than is necessary. The dimension of the other side of the module should be in units of $3^{\prime}$ and should be not less than $18^{\prime}$ if seminars are to be provided.
If the $43^{\prime \prime}$ table width is changed, the dimension of the module can be changed accordingly.

These theoretical calculations plus the evidence that can be found in existing libraries suggest that a module size can be determined that will not waste floor space.

Are "Dry" movable partitions sensible? Since one of the reasons for modular buildings is their flexibility, it follows that some type of movable partition is essential. All non-bearing partitions are movable, of course, but this discussion is limited to two kinds; Johns-Manville Transite and Mills metal partitions. Once erected both kinds serve well except that the sound deadening qualities of the metal partitions seem better. The metal partitions can be moved much more quickly and with much less messiness. The Transite partitions are harder to damage with scratches and should net have to be painted. They are harder to wash than the metal. The initial cost was about equal two years ago.

In operation, library users are not aware that the partitions are movable.

Problem of locating light switches. Since switches must be located at the time a building is planned and since moving them is expensive, there is a basic dilemma here. Locating them on the columns gives maximum control of the light fixtures for each module as a whole, but not when the module is subdivided. Unless there are master zone controls at a convenient location, purely local controls are expensive to administer. In the stacks, the ends of ranges are better places for switches than are columns.

It must be admitted, therefore, that the problem of locating light controls is a difficult one, and that some kind of combination of local and zone control is necessary. This is one of the penalties one must pay for the privilege of flexibility.

(Continued on page 142) 
Chronology of Library Planning at M.I.T. I9I6-I950, The Charles Hayden Memorial Library, Annual Report of the Director of Libraries for the Year 1948-49.

Dedicating the Charles Hayden Memorial Library-M.I.T. Library Annual 1950

Books in Libraries-The Librarian and the Building of a Library, by Vernon D. Tate (and) The Architect, and the University Library, by Ralph Walker

Statistical Data:

Cost

Dimensions

Lighting

Seating

Ceiling

Capacity

Exterior Material
3.5 Million

$218^{\prime} \times 189^{\prime}$

Silvray

500

$15^{\prime}$

400,00o Volumes

Shot-sawn Indiana

Limestone

\section{Michigan Scholarships and Fellowships}

Library Service Scholarships and Fellowships offered by the University of Michigan provide an opportunity for well qualified students enrolled in the Department of Library Science to acquire experience in one or more departments of the General Library. Awards are made to applicants who present evidence of superior academic ability and who can qualif for library assignments. T Scholarships, which carry a stipend of $\$ 1750$, will be awarded to successful candidates who have had little or no library training or experience. Fellowships, worth $\$ 2250$, are granted to students who have already had formal training or considerable library experience. Payment of the stipend is made in ten monthly installments from September 30 to mid-June. Each appointment is for one academic year and may be once renewed. I Scholars and Fellows may elect not more than half the number of course hours expected of full-time students in the Department, and must pay the regular University fees for these elections (six hours or less). They will be scheduled for thirty-six hours of service weekly in the General Library. Scholars and Fellows are allowed the Christmas and spring vacations scheduled in the University calendar. I Applications for both Scholarships and Fellowships should be made not later than May I. Announcement of the awards will be made about June I. I Inquiries and requests for application blanks should be directed to Samuel W. McAllister, associate director, General Library, University of Michigan, Ann Arbor, Michigan.

\section{Evaluation of the Modular Plan}

\section{(Continued from page 128)}

Can the interiors of modular libraries be attractive? The danger is monotony. This can be avoided through imaginative use of color, design of furniture, and arrangement of equipment. One can find good and bad solutions to the problem in the various modular buildings.

What effect does a modular library have on the behavior of its users? The testimony of librarians administering these libraries is uniformly favorable. The atmosphere is friendly and pleasant and readers respond accordingly. This tendency is encouraged by the fact that these buildings are all at- tractively furnished and all use a very informal arrangement of furniture.

Is the modular idea applicable to all libraries? The danger is that librarians will assume that it is. In libraries where there is no need for flexibility, where codes do not permit, or where the predominant style of architecture clashes, and where there is no need for economy, other methods are more suitable. Artificial circulation and treatment of air is essential in most climates in a modular building and this costs money. Furthermore, there can be no universally best way to plan a library. 